レーダ雨量計を用いた短時間降雨予測

Short-Term Precipitation Forcasting by Radar Raingauge

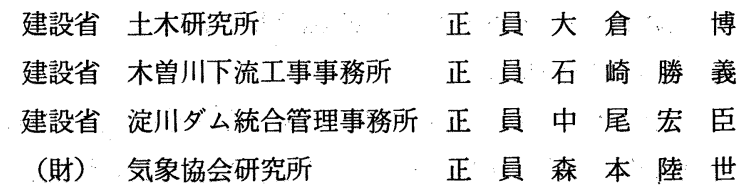

1. まえがき

昭和57年12月現在，建設省において 4 台のレーダ雨量計が稼動中であり， 2 台が建設または調節中である。従来の 地上雨量計に比較するとレーダ雨量計は非常に多くの降雨情報を得ることが出来る。すなわち,レーダ雨量計は降雨 の空間分布を連続して定量的に観測出来るととあに，降雨セルの移動方向からその規模の盛衰まであ把握するてとが 出来る。てのように今までの雨量計とまったく異なった雨量観測手段であるレーダ雨量計は, その利用においてあ異 なった扱いをする必要がある。

従来, 流出予流に用いていた流域平均雨量は数 $100 \mathrm{~km}^{2}$ 亿数台の雨量計によってティーセン法, あるいは等雨量線 法等によって求めた推定值であり, 降雨の面分布に大きく影響される。てれに対してレーダ雨量計では降雨を面的に 把握するため流域平均雨量推定に対する降雨の面分布の影響が少ない。レーダ雨量計は観測領域を平均 $9 \mathrm{~km}^{2}$ の観測 メッシュで分割しており，局地性降雨に対してあ十分対処しうるあのである。

本報告は, レーダ雨量計の特徴を生かした利用技術の 1 つとしてレーダ雨量計を用いた降雨予測手法を述べる。な お，本報告に用いたレーダ観測資料は建設省赤城山レーダ雨量計の資料である。

\title{
2. 降雨予測モデル
}

レーダ雨量計を用いた降雨予測は降雨エコーの外挿を基本としており, あっとも重要な要素は外挿に用いる移動べ クトルである。従来から, 外挿法による降雨予測法がいくつか提案され検討されている。てれらの手法は, 各々移動 ベクトルの設定方法が異なる。(1)運動学的方法(高層風による移流 $)^{1)}$, (2)変形テンソルによる方法 ${ }^{2)}$, (3)カルマン フィルターによる方法 ${ }^{3)}$, (4)相互相関関数による方法 ${ }^{4)}$, (5)重心の移動に着目する方法5)などである。

筆者等は, 流域平均雨量の自動的な予測を目的とし, (2) (5)の手法と同じくレーダーエコーのみから移動ベクトル を推定する方法を用い,オンライン予測に適した客観的なベクトル推定法を開発した。6),7)

雨域の移動ベクトルを適正に推定することは，降雨予測精度を向上させる大きなポイントとなる。移動べクトルの 推定を検討するにあたって次のような条件を設定した。

(1) 移動ベクトルの検出等は全て自動的に行う。

(2) 演算が容易で簡明なとと。

(3) 様々なタイプのエコーについても推定が可能なとと。

(4) 移動ベクトルがー意的に定まるてと。

(5) 発達・衰弱項の導入が容易であるてと。

また, エコーの動きに関しては次の仮定をした。「 $\delta \mathrm{t}$ 時間内のエコーの変形はあまり大きくない。また移動の主 たる要素は平行移動である(すなわち回転は考えない)。」

そこで, $\delta \mathrm{t}$ 時間へだたったエコー図から移動べクトルを推定するための着目点として, エコー形状の類似度をと った。乙れは，先にのべた相互関関数による方法と同じである。さらに，本手法においてはエコー図そのあのの類似 度を比較するのではなく, 適当な降雨強度を設定し, それ以上の值をすつメッシュを1, そうでないメッシュを 0 と するパターンの 2 値化を行って類似度を検討する。てうするてとにより, 雨量強度の発達・衰弱による見かけ上のエコ 一の移動にまどわされることが少なくなり，エコーの追跡が容易になる。

開発した予測モデルのフロチャートを図ー 1 に示す。手順は次の通りである。 
(1) 時刻 $\mathrm{t}$ と $\delta \mathrm{t}$ 時間 (15分〜30分) 前のエコーをレーダ観测から用意し, 各々, $\mathrm{ECHO}($ II ), $\mathrm{ECHO}$ ( I ) とする。

(2) レーダ雨量計の原始データは極座標データであり, これを直交座標 系のデータに変換する。直交座標変換されたメッシュの最少単位は 3 $\mathrm{km} \times 3 \mathrm{~km}$ である。

(3) 追跡エコーの雨量強度の最小閾値 $=\mathrm{C}$ を設定し, $\mathrm{E} \mathrm{C} \mathrm{HO} \mathrm{(} \mathrm{I} \mathrm{),} \mathrm{E}$ $\mathrm{CO}$ (II)を(2)で定めたメッシュでとに0，1の2 值パターンにおきか える。即ち, 各メッツュの雨量強度がCより大きい場合を $1, \mathrm{C} よ り$ 小さい場合を 0 として 2 值パターンに作りかえる(図一 2 )。Cの值 は $2 \mathrm{~mm} / \mathrm{H}$, または, 2 值化以前の各メッシュの雨量強度を大きい順に 並べ,メッシュの個数で強い方から $1 / 3$ 番目にあたる降雨強度とした。 このCの値の 2 つの設定法による降雨予測精度は大差なかった。

(4) $\mathrm{ECHO}$ ( I ) と E C HO ( II )を互いに平行移動し, 両者の交りの領 域において類似度を関連係数を用いて算出し, 関連係数マップ（図一 3）を作成する。

ここで関連係数は, 図ー 3 のような 2 值化された 2 枚のエコーパタ

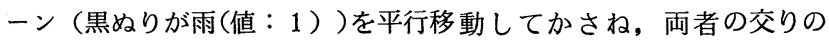
領域に打いて 2 枚のパターンメッシュのそれぞれ雨の有無による交叉 メッシュに対する個数 $\mathrm{n}$ を表ー 1 のマトリックスで表示する。これに

\begin{tabular}{|c|c|c|c|}
\hline II & 雨 あ り & 雨なし & \\
\hline 雨 あ り & $\mathrm{n}_{1}$ & $\mathrm{n}_{2}$ & $\mathrm{n}_{12}$ \\
\hline 雨なし & $\mathrm{n}_{3}$ & $\mathrm{n}_{4}$ & $\mathrm{n}_{34}$ \\
\hline & $\mathrm{n}_{13}$ & $\mathrm{n}_{24}$ & $\mathrm{~N}$ \\
\hline
\end{tabular}

表 -1 関連係数算出のためのマリックス

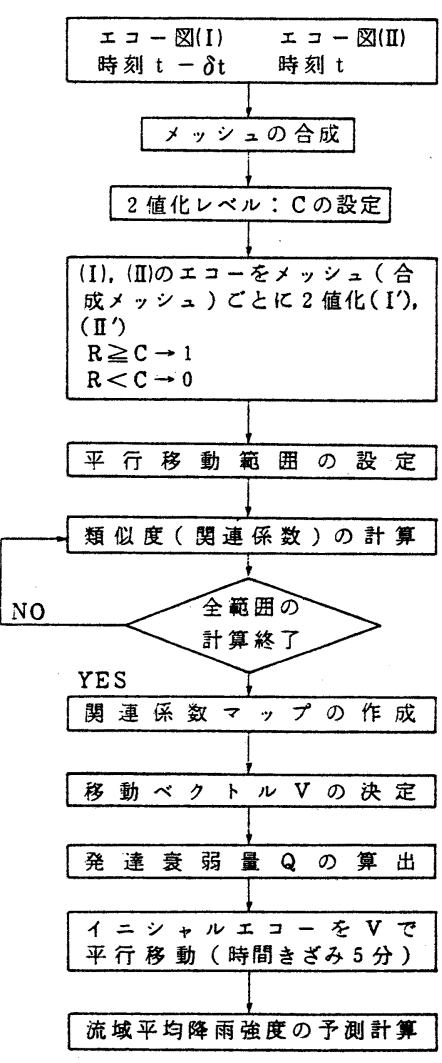

図-1 雨域追跡法による降雨予測の 方法

より関連係数 C A は

$$
C A=\frac{\left(n_{1} \cdot n_{4}-n_{2} \cdot n_{3}\right)}{\sqrt{n_{12} \cdot n_{34} \cdot n_{13} \cdot n_{24}}} \cdots
$$

で定義する。

(5) 関連係数マップ(図-3)の中央を始点, ピ 一クを終点とする移動ベクトルを求める。

(6)このようにして定まった移動べクトルを用 いて, 時刻 $\mathrm{t} の 2$ 值化前の実測エコーパター ン $\mathrm{E}_{0}($ イニシャルエコー) を移流して任意場 所の雨量を 5 分毎に計算する。乙れを「単純 移流」と呼ぶことにする。

\section{3. 発達衰弱項の降雨予測への導入}

検出された移動べクトルによってイニシアルエ コーを単純に移流するとイニシアルエコーの雨量
時刻 $\mathrm{t}-\delta \mathrm{t}$

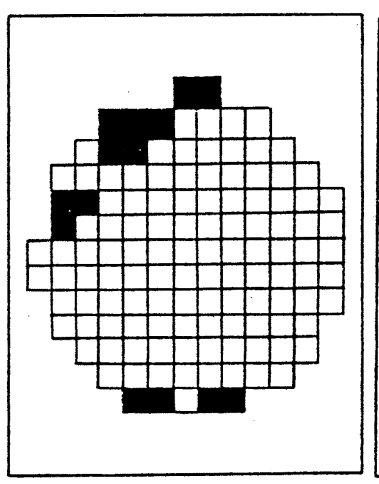

(a) $\mathrm{ECHO}$ (I)

図-2 平行移動するメッシュ
時刻 $\mathrm{t}$

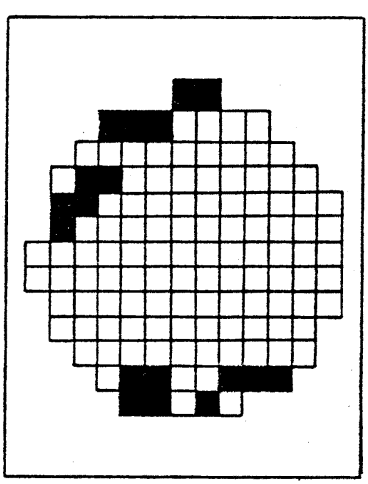

(b) $\mathrm{ECHO}$ (II) 


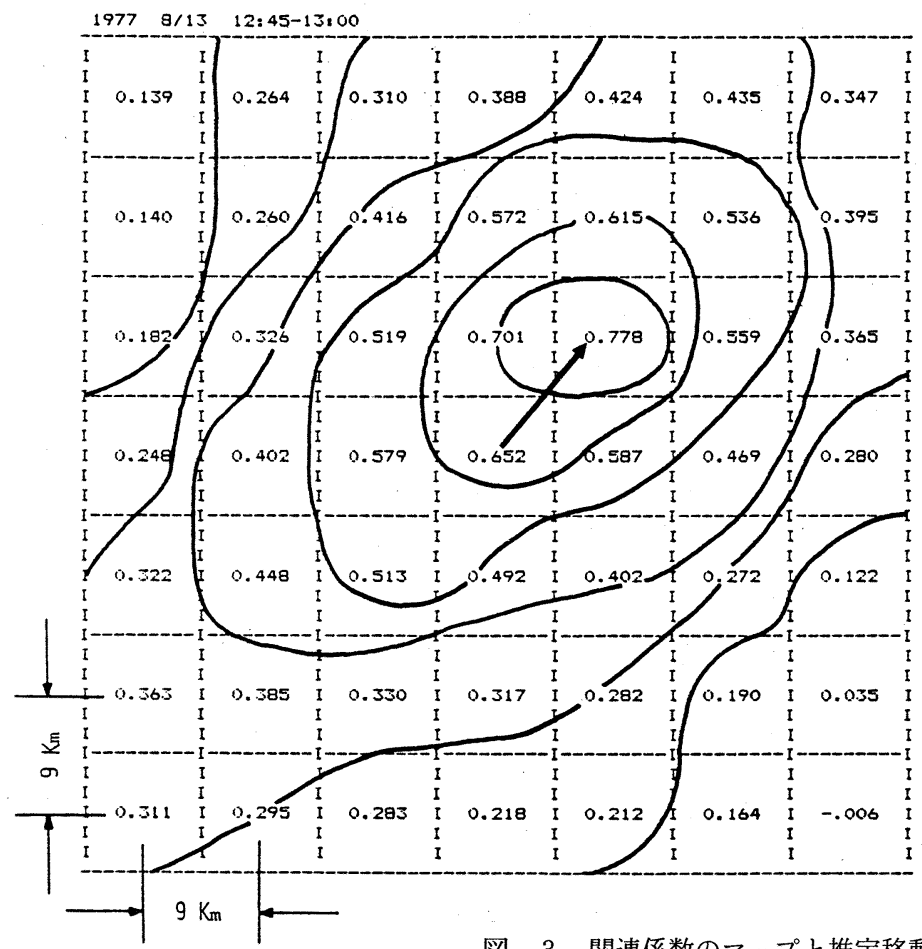

CORELATION COEFFICIENT MAP AND VECTORS FOR $9 \mathrm{Km} \times 9 \mathrm{Km}$ MESH

\begin{tabular}{ccr} 
C.A. & $V(M / S)$ & \multicolumn{1}{c}{ DIRECTION } \\
0.778 & 14.14 & 225.0 \\
0.701 & 10.00 & 180.0 \\
0.652 & 0.0 & 999.0 \\
0.615 & 22.36 & 206.6 \\
0.587 & 10.00 & 270.0 \\
0.579 & 10.00 & 90.0 \\
0.572 & 20.00 & 180.0 \\
0.559 & 22.36 & 243.4 \\
0.536 & 28.28 & 225.0 \\
0.519 & 14.14 & 135.0 \\
0.513 & 14.14 & 45.0 \\
0.492 & 10.00 & 0.0 \\
0.469 & 20.00 & 270.0 \\
0.448 & 22.36 & 63.4 \\
0.435 & 36.06 & 213.7 \\
0.424 & 31.62 & 198.4 \\
0.416 & 22.36 & 153.4 \\
0.402 & 14.14 & 315.0 \\
0.402 & 20.00 & 90.0 \\
0.395 & 36.06 & 236.3 \\
0.388 & 30.00 & 180.0 \\
0.385 & 28.28 & 45.0 \\
0.365 & 31.62 & 251.6 \\
0.363 & 36.06 & 56.3 \\
0.347 & 42.43 & 225.0 \\
0.330 & 22.36 & 26.6 \\
0.326 & 22.36 & 116.6 \\
0.322 & 31.62 & 71.0 \\
0.317 & 20.00 & 0.0 \\
0.311 & 42.43 & 45.0 \\
0.310 & 31.62 & 161.6 \\
0.295 & 36.06 & 33.7 \\
0.283 & 31.62 & 18.4 \\
0.282 & 22.36 & 333.4 \\
0.280 & 30.00 & 270.0 \\
& &
\end{tabular}

図一 3 関連係数のマップと推定移動ベクトル

強度は乙の値のままで外扦される。乙のため雨域 の雨量強度の変化の激しい降雨に対しては予測精 度が大きく低下することが予想される。従って, 予測精度を向上させるためには, 降雨の発達・衰 弱を予測モデルに組込む必要がある。

降雨域の発達・衰弱は気象現象と密接な関係が あり,レーダ以外の気像観測データとの関連から あ論じられることは明らかである。しかし, デー タ入手の速応性を考え, レーダ雨量計で観測され たエコーからの情報のみによって变化量を予測す 手法(以下,「発達・衰弱」と云う) を開発した。 図一 4 に降雨エコーの発達・衰弱を考慮したエコ ーパターンの予測フローを示す。全メッシュにつ いて, 現時点 $\mathrm{t}$ の実測エコー $\mathrm{E}_{0}$ と 30 分前のエコ 一を移流ベクトルVで移流して得られたエコー $\mathrm{E}_{-6}$ とを比較(雨量強度の差をとる)する。

$$
\mathrm{Q}_{6}=\mathrm{E}_{0}-\mathrm{E}_{-6} \text {. }
$$

同様にして, 25分前のエコーを25分間移流して, $\mathrm{E}_{-5}$ を求め $\mathrm{E}_{0}$ と比較する。乙のようにして, $\mathrm{Q}_{5}$, $\mathrm{Q}_{4}, \mathrm{Q}_{3}, \cdots \cdots \mathrm{Q}_{1}$ まで求める。乙れに平均して 発達・衰弱量 $\mathrm{Q}$ を得る。
(1)

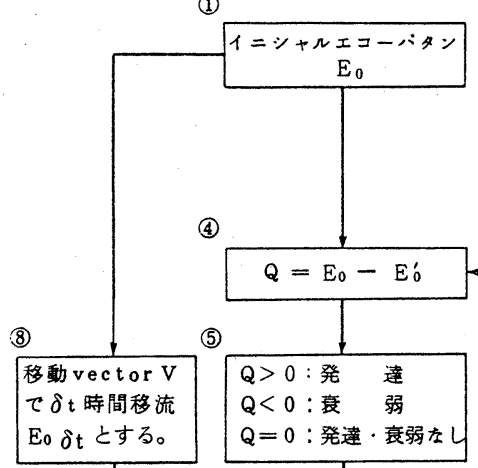

(7)

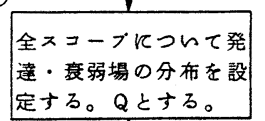

(7)

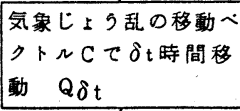

(9)

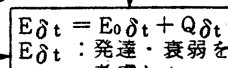
考愿したエ
(1)

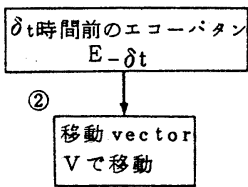

(3)

エコーハタン $E_{0}^{\prime}$

（注 1 )

Q：発䞗・衰弱の項

（注2）

気象しょら乱の移動へクトル Cは，前線・低気地九どのし 上ら乱の動さが考えられるが 実際にはすと小されスケー ルのじ上の乱。すかちメン スケールのし上ら乱々どの動 き荐入するべさでる。 (注 3 )

てのフロ一の精度は, 当然の ととながら移動へクトルVの 精度にかかわっている。 （注 4 ）

$\mathrm{Q}$ ：発迲・衰弱項が地形性の ののであり，移動しないと考 えるならば， C =0 とすると と花る。

図一4 発達・衰弱を考慮したエコーパターンの予測を行う手法 


$$
\mathrm{Q}=\frac{1}{6} \sum_{\mathrm{i}=1}^{6}(\mathrm{Qi} /(\mathrm{i} \cdot \delta \mathrm{t})) \cdot \mathrm{W}
$$

但し，Wは重み $(W=1 / 6), \delta t=5$ 分とする。

\section{4. モデルの適用結果}

モデルの適用限界は予測雨量の利用目的により異なる。このため, 予測降雨を純計処理し, 信頼性限界を判定す るための図を示した。

発達・衰弱の補正項Qの導入効果を評価するため, Qを考慮しないで単純移流により予测したあのと Qによる補正 をしたものとを比較した。

$3 \mathrm{~km} \times 3 \mathrm{~km}$ メッシュ で予測雨量が得られるが 評価地域を任意の $18 \mathrm{~km}$ $\times 18 \mathrm{~km}\left(324 \mathrm{~km}^{2}\right)$ に おける 1,2 ,及び 3 時間 の面積平均雨量の予測量 と実測值について検討した。

1977年 8 月 18 日, 1978 年 7 月 8 日, 1978年 7 月 11日，1978年 9 月 4 日の 降雨を用い予測雨量と実 測雨量とを統計処理し, 予 測雨量の信頼限界を算出し た。結果を図一 5 に示す。 図一 5 において 1 時間 及び 2 時間雨量の予測に 対しては発達・衰弱項の 導入効果は顕著でない。 「単純移流」の予測 1 時間 量 $20 \mathrm{~mm}$ に対する実测雨 量の平均と実効誤差はそ れぞれ $15.6 \mathrm{~mm}$ と $4.2 \mathrm{~mm}$ であり，予測 2 時間雨量 $20 \mathrm{~mm}$ に対し実測雨量の 平均と実効誤差はそれぞ れ $16.4 \mathrm{~mm}$ と $4.3 \mathrm{~mm}$ である。一方, 「発達・ 衰弱」の予測 1 時間量20 $\mathrm{mm}$ に対し実測雨量の平 均と実効誤差はそれぞれ $16.5 \mathrm{~mm}$ と $3.5 \mathrm{~mm}, 2$ 時間雨量 $20 \mathrm{~mm}$ に対し実 測雨量はそれぞれ $17.8 \mathrm{~mm}$
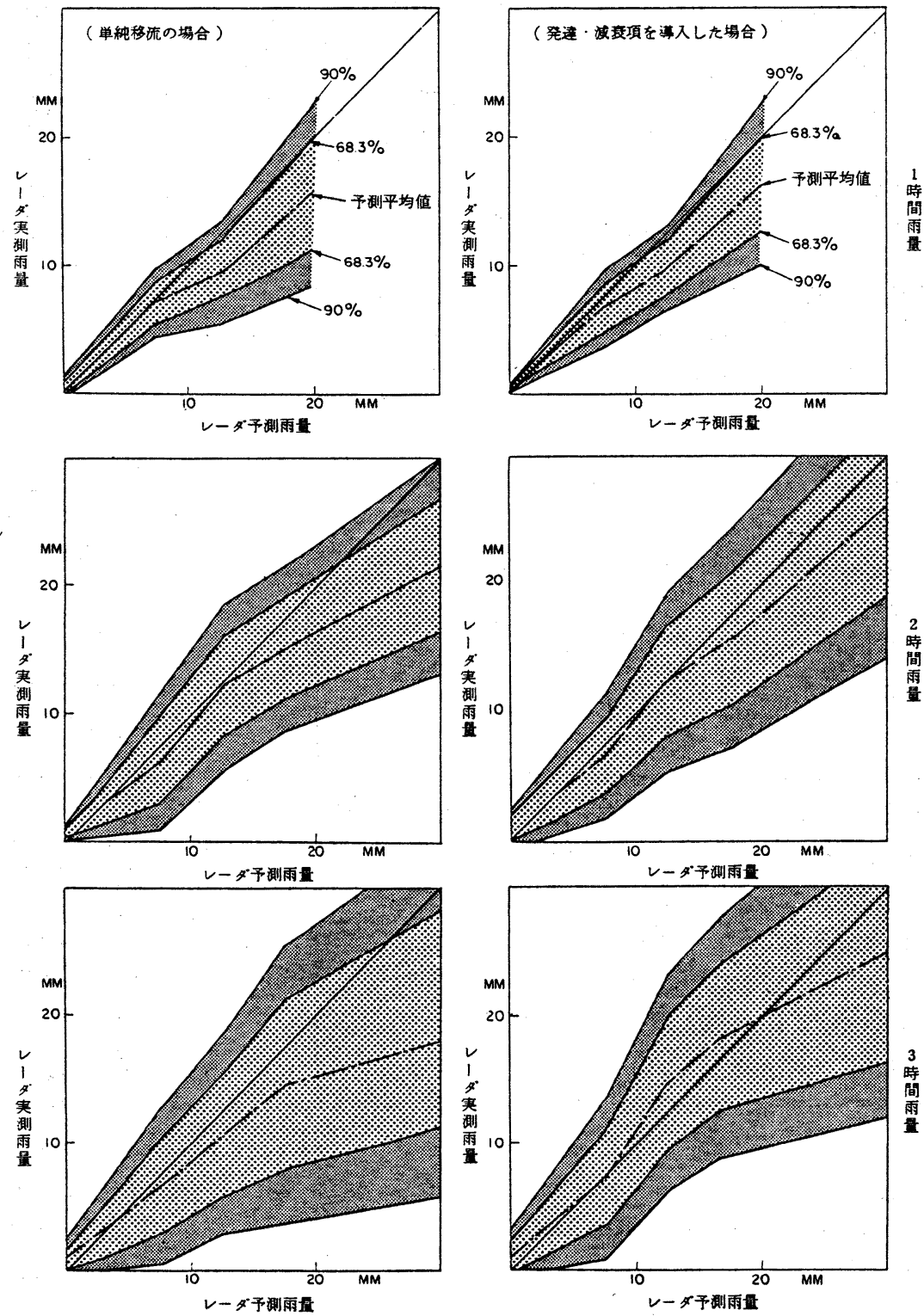

図-5 予測結果の信頼限界 


\section{と $5.6 \mathrm{~mm}$ である。}

3 時間雨量の予測では発達衰弱項の導入効果を若干認めることができる。「単純移流」の予測 3 時間雨量 $20 \mathrm{~mm} に$ 対し実測雨量の平均と実効誤差はそれぞれ $15.2 \mathrm{~mm}$ と $6.9 \mathrm{~mm}$ であるが,「発達・衰弱」の平均と実効誤差はそれぞれ $20.1 \mathrm{~mm}$ と $6.6 \mathrm{~mm}$ である。

てれは, 1 時間程度先の降雨予測に対しては, 降雨域の变化の程度は平野など場所によってあまり大きくなく $\mathrm{Q} の$ 導入の必要性も高くないためである。

しかし, 図一6(a)のエコーの移動方向の断面沿に抽出したQ值が示すように, Qは明らかに標高の変化に大きな相 関がある。図一 6 (b), (c), (d)は(a) と同一断面沿に扔ける降雨予測量 ( 1 時間雨量) または実測雨量を示す。(b)は「単 純移流」, (c)は「発達・衰弱」, (d)は実測值である。実測值に対し, 「発達・衰弱」の再現性は非常によいが, 単純

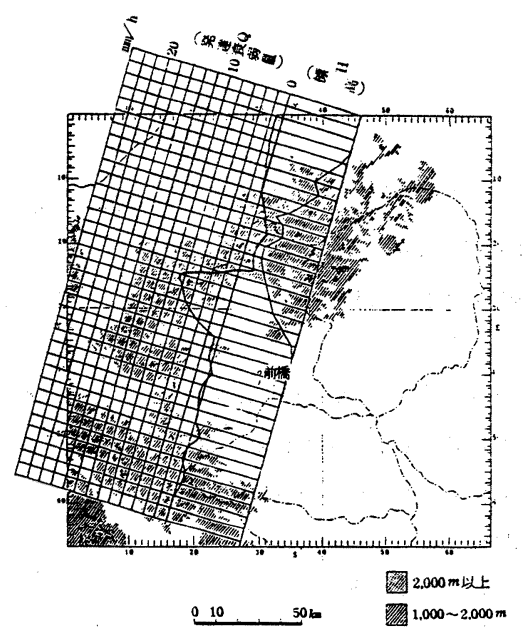

(a) 発達衰弱量(Q). 1978.8.17. $02: 45 \sim 3: 00$
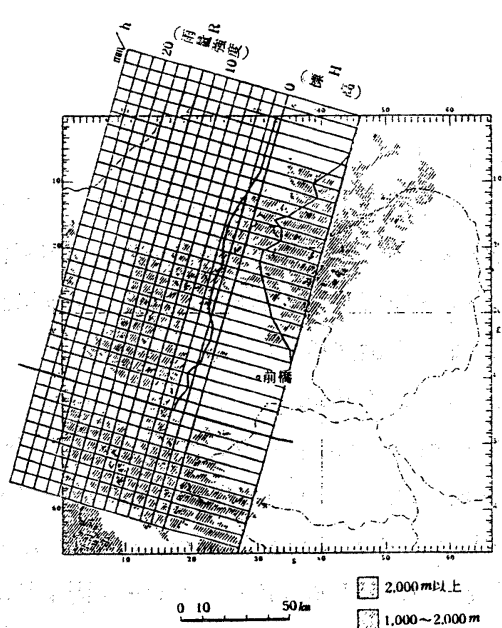

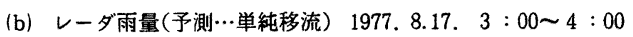

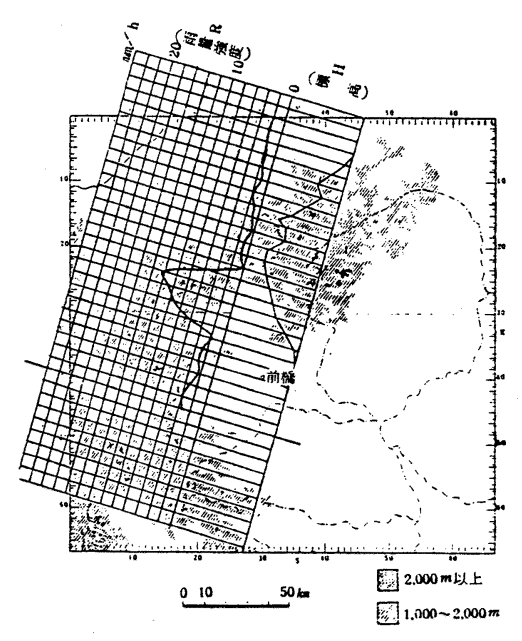

(c) レーダ雨量 (予测…発達・衰弱項導入)

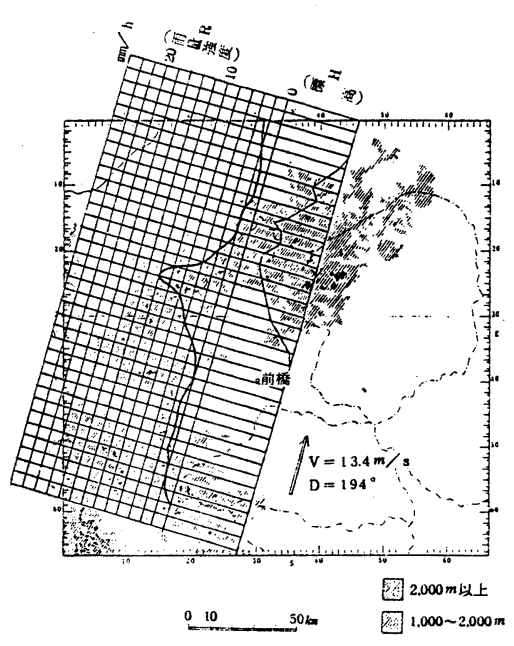

(d) レーダ雨量(雨量) 1977. 8.17. 3:00 4:00

1977. 8. 17. $3: 00 \sim 4: 00$

図一 6 地形特性と発達・衰弱項の導入効果 
移流したものは非常に異なっている。

\section{5. まとめ}

レーダ雨量計の観測データを用いて自動的に降雨予測する手法を述べた。ての手法は関連係数法を用いて検出した 移流ベクトルに従って予測開始時刻の降雨エコーを外插するてとを基本としている。移流にあたり雨域の発達・衰弱 項の導入を検討した。発達・衰弱項導入の評価は面積 $342 \mathrm{~km}^{2}$ の面積平均雨量を予測し, ての予測値を統計処理して 行った。この結果, 3 時間雨量に対しては若干の効果が認められたが, 1,2 時間雨量に対しては有為な効果は得ら れなかった。しかし, 統計処理を行う前の 1 時間予測雨量の山岳部において発達・衰弱項導入の効果の著しい例が認 められた。モデルの適用限界は利用目的により異なる。このため, 信頼性限界を判定する図を示した。

\section{参考文献}

1）たとえば,立平良三・牧野義久(1974）：デジタル化されたエコーパターンの予報への利用, 研究事報26巻.

2 ) 竹内邦良 (1978)：雨域・雨量強度分布变化の短時間予測. 第22回水理講演会論文集.

3 ）下垣久・室田明・江藤剛治（1978）：雨量観測レーダーによる降雨量分布の解析とそのオン・ライン予測. 第22 回水理講演会論文集.

4) たとえば, Bellon, A. and G.L. Austin (1978) : The evaluation of two years of real-time operation of a short-term precipitation forecasting procedure (SHARP). J. Appl. Meteor., 17, 1778-1787.

5) Wilk, K. E. and K. C. Gray (1970) : Processing and analysis techniques used with the NSSL weather radar system. Proc. 14th Radar Met. Conf., 369-374.

$6)$ 石崎・中尾・森本 (1980) : レーダ雨量計による短時間降雨予測. 第 35 回年講.

7 ) 石崎・中尾・森本 (1981) : レーダ雨量計による短時間降雨予測 (発達・衰弱項の導入). 第36回年講. 